\title{
Article \\ Effect of Drip Fertigation with Nitrogen on Yield and Nutritive Value of Melon Cultivated on a Very Light Soil
}

\author{
Roman Rolbiecki $^{1}(\mathbb{D})$, Stanisław Rolbiecki ${ }^{1} \mathbb{D}$, Anna Figas $^{2} \mathbb{D}$, Barbara Jagosz $^{3} \mathbb{D}^{\mathbb{D}}$, Dorota Wichrowska ${ }^{4} \mathbb{D}$, \\ Wiesław Ptach ${ }^{5}$, Piotr Prus ${ }^{6, *}$, Hicran A. Sadan ${ }^{1}$, Pal-Fam Ferenc ${ }^{7}$, , Piotr Stachowski ${ }^{8}(\mathbb{D})$ and \\ Daniel Liberacki ${ }^{8}$ (D)
}

check for updates

Citation: Rolbiecki, R.; Rolbiecki, S.; Figas, A.; Jagosz, B.; Wichrowska, D.; Ptach, W.; Prus, P.; Sadan, H.A.; Ferenc, P.-F.; Stachowski, P.; et al. Effect of Drip Fertigation with Nitrogen on Yield and Nutritive Value of Melon Cultivated on a Very Light Soil. Agronomy 2021, 11, 934. https://doi.org/10.3390/ agronomy11050934

Academic Editors: Nikolaos

Monokrousos and Efimia

M. Papatheodorou

Received: 26 March 2021

Accepted: 5 May 2021

Published: 9 May 2021

Publisher's Note: MDPI stays neutral with regard to jurisdictional claims in published maps and institutional affiliations.

Copyright: (c) 2021 by the authors. Licensee MDPI, Basel, Switzerland. This article is an open access article distributed under the terms and conditions of the Creative Commons Attribution (CC BY) license (https:// creativecommons.org/licenses/by/ $4.0 /)$.
1 Department of Agrometeorology, Plant Irrigation and Horticulture, Faculty of Agriculture and Biotechnology, UTP University of Science and Technology in Bydgoszcz, 85-029 Bydgoszcz, Poland; rolbr@utp.edu.pl (R.R.); rolbs@utp.edu.pl (S.R.); hicran_sadan_76@hotmail.com (H.A.S.)

2 Department of Agricultural Biotechnology, Faculty of Agriculture and Biotechnology, UTP University of Science and Technology, 85-029 Bydgoszcz, Poland; figasanna@utp.edu.pl

3 Department of Plant Biology and Biotechnology, Faculty of Biotechnology and Horticulture, University of Agriculture in Krakow, 31-120 Krakow, Poland; Barbara.Jagosz@urk.edu.pl

4 Department of Microbiology and Food Technology, Faculty of Agriculture and Biotechnology, UTP University of Science and Technology, 85-029 Bydgoszcz, Poland; wichrowska@utp.edu.pl

5 Department of Remote Sensing and Environmental Research, Institute of Environmental Engineering, Warsaw University of Life Sciences, 02-776 Warszawa, Poland; wieslaw_ptach@sggw.edu.pl

6 Laboratory of Economics and Agribusiness Advisory, Faculty of Agriculture and Biotechnology, UTP University of Science and Technology in Bydgoszcz, 85-029 Bydgoszcz, Poland

7 Institute of Plant Production, Kaposvár Campus, Hungarian University of Agriculture and Life Sciences (MATE), H-7400 Kaposvár, Hungary; Pal-Fam.Ferenc.Istvan@szie.hu

8 Department of Land Improvement, Environmental Development and Spatial Management, Faculty of Environmental Engineering and Mechanical Engineering, Poznan University of Life Sciences, 60-649 Poznań, Poland; piotr.stachowski@up.poznan.pl (P.S.); daniel.liberacki@up.poznan.pl (D.L.)

* Correspondence: piotr.prus@utp.edu.pl; Tel.: +48-52-340-8084

Abstract: Most species of Cucurbitaceae respond favorably to irrigation, especially when combined with fertilizers. The effect of drip irrigation combined with nitrogen fertigation in melon grown on a very light soil in Central Poland, during 2013-2015, was evaluated. The field experimental design was a split-plot with four replications. Two factors were studied: (1) irrigation treatments applied in two combinations-drip irrigation + broadcast nitrogen fertilization (control), and drip irrigation + fertigation with nitrogen; (2) two cultivars-Melba and Seledyn. The total marketable yield of fruits, weight of a single fruit, and the concentration of dry matter, total sugars, monosaccharides, ascorbic acid, total carotenoids, and polyphenols were evaluated. Tested factors presented a significant effect both on the yield and nutritive value characteristics. Drip irrigation combined with nitrogen fertigation, comparing to the control, notably improved yields and nutritional value of fruits. Seledyn produced better yields than Melba. This study shows that on very light soil, with low water and nutrient retention capacity, melon should be drip-irrigated and nitrogen-fertigated to obtain the best cultivation results.

Keywords: Cucumis melo L.; chemical composition; cultivar; drip irrigation; fruit quality

\section{Introduction}

Melon (Cucumis melo L.) belongs taxonomically to the Cucurbitaceae family, which also includes vegetables, such as cucumber, pumpkin, squash, watermelon, and gourds. In many countries around the world, melon fruit is of considerable economic importance. World production of this species in 2018 was estimated at 40 million tons per year. The main melon-producing country is China (12.7 million tons per year), followed by Turkey, Iran, and India (1.8 to 1.2 million tons per year) [1]. 
There are many cultivars of melon, which differ mainly in shape, color, and taste [2]. Melon fruits are valuable in terms of nutritional and bioactive properties. This species is a very good source of carotenoids ( $\alpha-, \beta$-carotene, and $\beta$-cryptoxanthin), folic acid, pectins, as well as many vitamins (including B group) and minerals (mostly potassium, iron, and magnesium), polyphenols, such as flavonoids and phenolic acids, and fatty acids (including oleic, linoleic, and palmitoleic acids). Melon is a fruit appreciated not only for its taste and dietary qualities, but also its healing properties, thanks to which it is also used in the cosmetics industry [3-6].

In Poland, due to unfavorable climatic conditions, the melon is grown as a noncommercial species. However, the interest in melon cultivation is clearly growing every year. Currently, the Polish National List of Vegetable Plant Varieties includes seven cultivars that are suitable for cultivation in Poland, and their number is systematically growing [7]. This species is photophilous and thermophilic, with a very high water requirement. Melon plants are very sensitive to spring and autumn frosts, which negatively affect growth and development, and thus also the fruit yield [8]. The highest sensitivity of melon plants to water deficit is observed during the fruit setting period [9].

Due to the rising interest in melon growing in Poland, it is necessary to broaden the knowledge about the methods of its cultivation in temperate climatic conditions. Field production of melon largely depends on the thermal conditions and precipitation during the growing season. An important factor in obtaining high- and good-quality crops is ensuring optimal soil moisture during the vegetation period of this species. In Poland, the water requirements of plants from the Cucurbitaceae family are estimated at around $400 \mathrm{~mm}$ during the growing season. The main reason for the high water needs of plants belonging to this family is their high fertility and the production of much aboveground mass with a high coefficient of transpiration (as the ratio of the amount of water excreted to the production of dry matter) [10]. It is generally accepted that irrigation significantly affects both the melon yield and the components of the melon yield grown under semiarid climatic conditions [9,11-13]. Many studies have shown that the field cultivation of melon should be carried out using irrigation treatments [11-16]. It was found that production factors such as water and nutrients (nitrogen, phosphorus, potassium) most often limit the possibility of obtaining a higher yield of melon fruit $[17,18]$. Drip irrigation combined with fertigation is a good way to increase the efficiency of water use and yield of Cucurbitaceae. It was also found that drip irrigation performed during the cultivation of Cucurbitaceae and other vegetables sensitive to climatic conditions during the growing season clearly increases their nutrient concentration $[19,20]$. Drip fertigation ensures precise administration of appropriate amounts of nutrients directly to the root zone. Accurate and uniform application of macro- and micronutrients adequately meets the needs of crops during the growing season [21-23].

The objective of this study was to evaluate the effect of drip irrigation combined with nitrogen fertigation on the melon fruit yield and nutritive value characteristics. As a control, drip irrigation combined with broadcast fertilization was used. The total marketable yield of fruits, weight of a single fruit, and the concentration of dry matter, total sugars, monosaccharides, ascorbic acid, total carotenoids, and polyphenols of two melon cultivars (Melba and Seledyn) were evaluated. The experiment was carried out on very light soil in a region of high precipitation deficit; hence, the advisability of irrigation treatments in this area is justified.

\section{Materials and Methods}

\subsection{Field Experiment Description}

The field experiment involving the drip fertigation of two melon (Cucumis melo L.) cultivars, namely Melba and Seledyn, was conducted in Kruszyn Krajeński near Bydgoszcz $53^{\circ} 04^{\prime} 53^{\prime \prime} \mathrm{N}, 17^{\circ} 51^{\prime} 52^{\prime \prime} \mathrm{E}$ (Central Poland). The area has precipitation deficits, an extremely unfavorable water balance, and high frequency of long periods without rainfall [19,22-29]. The study was carried out in the years 2013-2015. The plants were grown using standard 
crop management practices recommended for melon cultivation in Poland. The study was carried out on very light soil with a weak and very weak rye-soil complex. Based on the percentage content of individual granulometric fractions, this soil was classified as sand [30]. The soil of the experimental field contained such fractions as: sand- $86.97 \%$ (from $2.0 \mathrm{~mm}$ to $0.05 \mathrm{~mm}$ ), silt $-12.28 \%$ (from $0.05 \mathrm{~mm}$ to $0.002 \mathrm{~mm}$ ), and clay $0.75 \%(<0.002 \mathrm{~mm})$. The average content of total organic carbon and concentration total nitrogen in the soil was $9.6 \mathrm{~g} \mathrm{~kg}^{-1}$ and $0.9 \mathrm{~g} \mathrm{~kg}^{-1}$, respectively. The experimental soil was characterized by a low capacity for water retention. The water reserve to $0.6 \mathrm{~m}$ depth of soil at field capacity was $72.7 \mathrm{~mm}$, at wilting point $29.1 \mathrm{~mm}$, and the available water $43.6 \mathrm{~mm}$.

The experiment was conducted as a split-plot design with four replications. Two factors were used in the study. The first factor was the drip fertigation with nitrogen applied in two combinations: (1) drip irrigation + broadcast nitrogen fertilization (control); (2) drip irrigation + fertigation with nitrogen. The second factor was two melon cultivars: Melba and Seledyn.

Melon seedlings were transplanted at $0.6 \mathrm{~m}$ within rows and $1.6 \mathrm{~m}$ between rows. The area of each harvest plot was $12 \mathrm{~m}^{2}$ and included 15 melon plants, and the whole experimental plot size was $274 \mathrm{~m}^{2}$. Before planting the seedlings, cultivating and harrowing were performed. The fertilization consisted of 120:100:150 kg ha ${ }^{-1}$ of nitrogen: phosphorus: potassium. The fertilization of phosphorus and potassium was carried out every year in early spring. The doses of potassium (potash salt) and phosphorus (superphoshate) fertilization depended on the abundance of these nutrients in the soil, based on the soil analysis carried out each year. Nitrogen fertilization (ammonium nitrate) was applied in three doses of $40 \mathrm{~kg} \mathrm{~N}$ ha $^{-1}$ during the growing season for both variants of fertilization. Fertigation was carried out using a proportional fertilizer dispenser. Drip irrigation and drip fertigation were carried out using the "T-Tape" drip line with a distance of $20 \mathrm{~cm}$ between the emitters. The efficiency of a single emitter was $1 \mathrm{l} \mathrm{h}^{-1}$. The distance between the drip lines was $1.6 \mathrm{~m}$. Water from the subsurface well was used for irrigation. The quality and physical and chemical properties of the irrigation water used complied with the quality standards for irrigation water. Drip irrigation was started when the water potential in the soil was close to $-40 \mathrm{kPa}$ and finished when the water potential in the soil was close to $-10 \mathrm{kPa}$. The end of irrigation treatments was determined on the basis of soil water potential at field water capacity, measured with a tensiometer. The tensiometers have been installed at every variant of the experiment at the depth of $25 \mathrm{~cm}$. The dates of planting during the particular growing seasons were in the second week of June. Harvesting took place at the physiological stage of fruit ripeness (from the beginning of 3rd week of August till 1st week of September). Ripe fruits were picked progressively as they matured. In the experiment, the total marketable yield of melon fruits ( $\left.\mathrm{tha}^{-1}\right)$ and weight of single melon fruit $(\mathrm{kg})$ were assessed.

\subsection{Nutritive Value Assessment}

To carry out a nutritional assessment the fresh melon fruits, one fruit from all plants in one plot was cut into a $5 \mathrm{~cm}$ wedge and then cut into 1 -cm-thick slices. The frozen material was lyophilized (model Alpha 1-4 LDplus, Donserv, Warszawa, Poland), in order to achieve a permanent weight, and then it was ground to a fine powder (the particles were 0.3-0.5 mm in size) and was milled using the ultracentrifuge (Model FW177, Chemland, Stargard, Poland). The ground samples were stored in the dark, in bags, which were placed in desiccators for further analysis.

The total dry matter content of 'Melba' and 'Seledyn' melon fruits was determined using the drying technique according to the methodology of the Association of Official Analytical Chemists [31].

Carbohydrate analyses were performed according to Talburt and Smith's [32] procedures. For reducing sugar concentration assessment, one gram of freeze-dried material sample was placed in a $250 \mathrm{~mL}$ bottle; $150 \mathrm{~mL}$ of distilled water was then added and it was shaken vigorously. One milliliter of the filtrate was mixed with $3 \mathrm{~mL}$ of DNP reagent 
in a test tube and then heated in a water bath at $95{ }^{\circ} \mathrm{C}$ for $6 \mathrm{~min}$. Absorbance of the mixture was measured using a spectrophotometer at a wavelength of $600 \mathrm{~nm}$. The reducing sugar concentration was then estimated using the standard curve of glucose. The total soluble carbohydrate was determined after hydrolysis of sugars. After filtration, $40 \mathrm{~mL}$ of the filtrate was taken, and 2 drops of concentrated $\mathrm{HCl}$ were added. The samples were warmed in a water bath for $30 \mathrm{~min}$. After cooling, the mixture was neutralized using concentrated $\mathrm{NaOH}$ until $\mathrm{pH} 8.0$ was reached. Next, $1 \mathrm{~mL}$ of the filtrate was mixed with $3 \mathrm{~mL}$ of DNP reagent and the procedure for determining the concentration of reducing sugars was followed. The results were converted to fresh weight taking into account the percentage of dry weight in the fresh matter.

Ascorbic acid reducing sugar concentration was assessed according to Kapur et al. [33]. Ten grams of fresh melon sample was homogenized with $25 \mathrm{~mL}$ of $2 \%$ oxalic acid solution and quantitatively transferred into a $50 \mathrm{~mL}$ volumetric flask and shaken gently to homogenize the solution. Then, it was diluted up to the mark with oxalic acid solution. The obtained solution was then filtered and centrifuged at $4000 \mathrm{rpm}$ for $15 \mathrm{~min}$, after which the supernatant solution was used for spectrophotometric determination (UV-1800, UV Spectrophotometer System, Shimadzu, Kyoto, Japan) of ascorbic acid concentration. Ascorbic acid is oxidized to dehydroascorbic acid by adding bromine water. After this, L-dehydroascorbic acid reacts with 2,4-DNPH and produces an osazone, which, treated with $85 \% \mathrm{H}_{2} \mathrm{SO}_{4}$, forms a red-colored solution. A typical calibration plot was made and used to determine the concentration of ascorbic acid in the investigated samples.

Total carotenoids in melon samples were extracted by procedures described by Herrero-Martinez et al. [34]. Ten grams of lyophilized melon was blended with $100 \mathrm{~mL}$ saturated anhydrous sodium carbonate and mixed with a mechanical blender. Ten grams of the mixture was transferred into a centrifuge tube, $20 \mathrm{~mL}$ tetrahydrofuran was added, and it was mixed for 2 min under cold water. The mixture was centrifuged at $5000 \mathrm{rpm}$ for $5 \mathrm{~min}$ and the supernatant was collected. Extraction was performed by adding $15 \mathrm{~mL}$ dichloromethane and $15 \mathrm{~mL}$ of $10 \% \mathrm{w} / \mathrm{v} \mathrm{NaCl}$ into the supernatant and shaking it for $2 \mathrm{~min}$. The extraction was repeated twice; the organic layer was collected and evaporated under nitrogen steam. The residue was kept at $-20{ }^{\circ} \mathrm{C}$, reconstituted with $5 \mathrm{~mL}$ dichloromethane, and diluted (1/40-fold) with dichloromethane prior UV measurements (Shimadzu UV-1800, UV-Vis spectral photometer system, Japan). Detection was performed at $450 \mathrm{~nm}$ according to the procedure reported in the Polish Standard [35]. Standard $\beta$-carotene for identification was prepared in dichloromethane to obtain $4 \mu \mathrm{g} \mathrm{mL}^{-1}$.

Total phenolic reducing sugar concentration was determined using the Folin-Ciocalteu reagent (Sigma-Aldrich, Darmstadt, Germany) according to the method of Singleton and Orthofer [36]. A volume of $0.5 \mathrm{~mL}$ of Folin-Ciocalteu reagent previously diluted with distilled water $(1: 10)$ was mixed with $0.1 \mathrm{~mL}$ of each sample. The solution was allowed to stand for $5 \mathrm{~min}$ at $25^{\circ} \mathrm{C}$ before adding $1.7 \mathrm{~mL}$ of sodium carbonate solution (20\%). Then, $10 \mathrm{~mL}$ of distilled water was added to the mixture, and the absorbance was measured at $\lambda=735 \mathrm{~nm}$ after $20 \mathrm{~min}$ of incubation with agitation at room temperature. Results were expressed in mg of gallic acid equivalents (GAE) per $\mathrm{kg}$ of fresh sample.

\subsection{Statistical Analysis}

All the experimental data were tested for differences by two-way ANOVA using of Statistica ${ }^{\circledR} 13.1$ package. The significance of differences (LSD-lowest significant difference) was evaluated using the Tukey multiple confidence intervals for the significance level of $p=0.05$.

\subsection{Weather Conditions}

The average air temperature in Kruszyn Krajeński in the vegetation period, i.e., from 1 April to 30 September in the years 2013-2015, was $14.9{ }^{\circ} \mathrm{C}$ and was $0.3^{\circ} \mathrm{C}$ higher than the mean for the long-term period 1986-2015 (Table 1). The warmest month of the growing season in 2013-2015 was July, with a mean temperature of $19.6^{\circ} \mathrm{C}\left(0.8^{\circ} \mathrm{C}\right.$ above the mean 
for long-term period). In 2014 , the highest average air temperature $\left(15.4^{\circ} \mathrm{C}\right)$ was recorded, which was $0.8^{\circ} \mathrm{C}$ higher compared to the mean for the long-term period.

Table 1. Average air temperature $\left({ }^{\circ} \mathrm{C}\right)$ data during the vegetation period of Melba and Seledyn melon cultivars in the years 2013-2015.

\begin{tabular}{cccccccc}
\hline \multirow{2}{*}{ Study Years } & \multicolumn{7}{c}{ Months of Vegetation Period } \\
\cline { 2 - 6 } & IV & V & VI & VII & VIII & IX & \\
\hline 2013 & 7.0 & 14.2 & 17.4 & 18.9 & 18.1 & 10.7 & 14.4 \\
2014 & 9.9 & 13.3 & 16.0 & 21.5 & 17.2 & 14.4 & 15.4 \\
2015 & 7.5 & 12.4 & 15.7 & 18.5 & 20.9 & 13.8 & 14.8 \\
Mean for 2013-2015 & 8.1 & 13.3 & 16.4 & 19.6 & 18.7 & 10.0 & 14.9 \\
$\begin{array}{c}\text { Mean for long-term } \\
\text { period 1986-2015 }\end{array}$ & 8.1 & 13.3 & 16.3 & 18.8 & 18.0 & 13.1 & 14.6 \\
\hline
\end{tabular}

The mean sum of precipitation in Kruszyn Krajeński in the period from 1 April to 30 September, for the years 2013-2015, amounted to $279.2 \mathrm{~mm}$ and was $31.4 \mathrm{~mm}$ lower than the mean for the long-term period 1986-2015 (Table 2). The highest precipitation during the vegetation period occurred in 2013 and amounted to $354.3 \mathrm{~mm}(43.7 \mathrm{~mm}$ above the mean for the long-term period). In the 2015 growing season, the lowest total precipitation was recorded, amounting to $193.3 \mathrm{~mm}$, and was $117.3 \mathrm{~mm}$ below the mean for the long-term period. The mean precipitation in April, June, July, and August in 2013-2015 was lower than the mean for the long-term period. The highest monthly precipitation $(91.7 \mathrm{~mm}$ in May and $79.0 \mathrm{~mm}$ in July) was noted in the growing season of 2013.

Table 2. Precipitation $(\mathrm{mm})$ data during the vegetation period of Melba and Seledyn melon cultivars in the years 2013-2015.

\begin{tabular}{|c|c|c|c|c|c|c|c|}
\hline \multirow{2}{*}{ Study Years } & \multicolumn{6}{|c|}{ Months of Vegetation Period } & \multirow{2}{*}{ Sum } \\
\hline & IV & $\mathbf{V}$ & VI & VII & VIII & IX & \\
\hline 2013 & 13.6 & 91.7 & 49.3 & 79.0 & 56.6 & 64.1 & 354.3 \\
\hline 2014 & 40.7 & 65.7 & 44.9 & 55.4 & 57.3 & 25.9 & 289.9 \\
\hline 2015 & 15.6 & 21.6 & 33.0 & 50.4 & 20.3 & 52.4 & 193.3 \\
\hline Mean for 2013-2015 & 23.3 & 59.7 & 42.4 & 61.6 & 44.7 & 47.5 & 279.2 \\
\hline $\begin{array}{l}\text { Mean for long-term } \\
\text { period 1986-2015 }\end{array}$ & 26.9 & 50.2 & 54.9 & 71.4 & 59.7 & 47.5 & 310.6 \\
\hline
\end{tabular}

\subsection{Irrigation Water Rates}

The seasonal irrigation water rates used in the growing of Melba and Seledyn melon cultivars were inversely proportional to rainfall amount during the irrigation period. Relationship between precipitation $(\mathrm{mm})$ and seasonal irrigation water rates $(\mathrm{mm})$ of Melba and Seledyn melon cultivars in June-August in the years 2013-2015 is shown in Figure 1. The melon irrigation period, mean for 2013-2015, began on 13 June and ended on 4 August and lasted for an average of 53 days. The shortest irrigation period, only 11 days, was carried out in 2013. On average, in 2013-2015, during the irrigation period, 14 single waterings took place. The average seasonal dose, in the years 2013-2015, was $142.2 \mathrm{~mm}$ and ranged from $104.5 \mathrm{~mm}$ in 2013 to $169.0 \mathrm{~mm}$ in 2014 . Both experimental treatments received the same amount of irrigation water. 


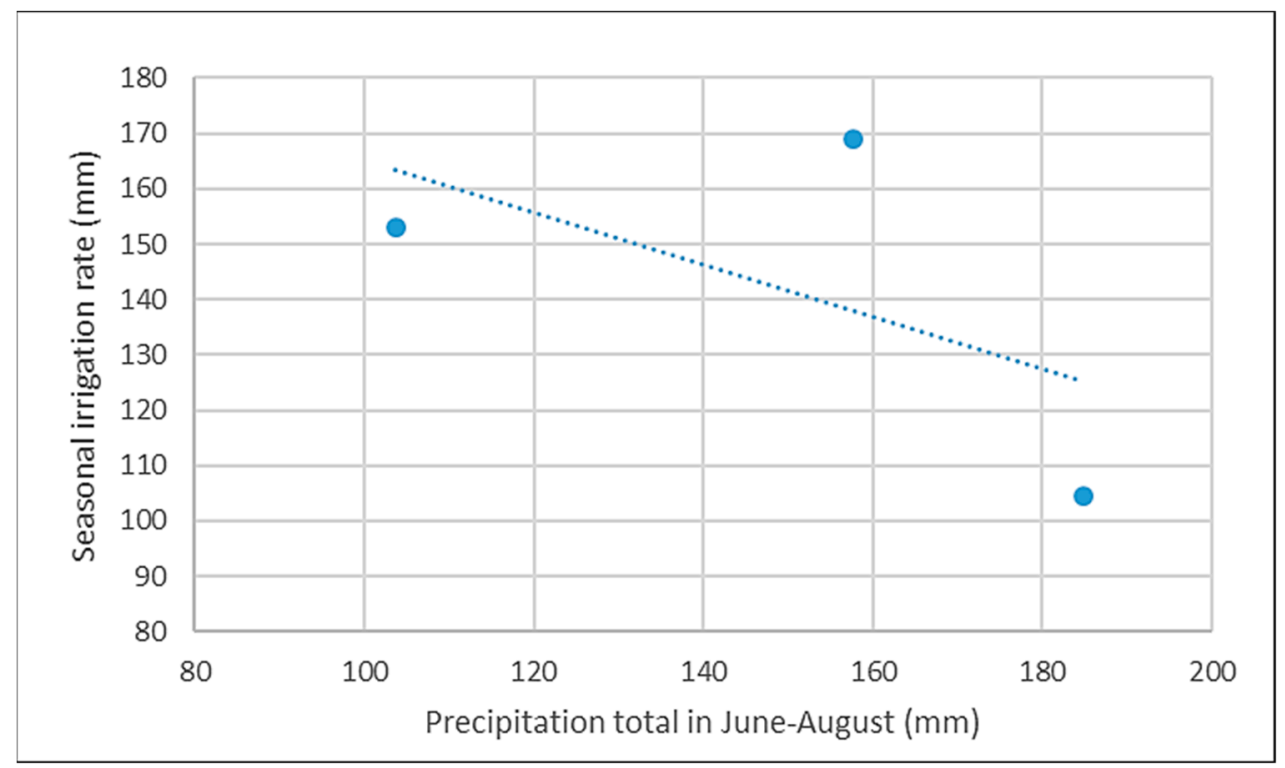

Figure 1. Relationship between precipitation $(\mathrm{mm})$ and seasonal irrigation water rates $(\mathrm{mm})$ of Melba and Seledyn melon cultivars in June-August in the years 2013-2015.

\section{Results and Discussion}

In the control field (the drip irrigation combined with broadcast nitrogen fertilization), the mean total marketable melon yield in the years 2013-2015 was $26.38 \mathrm{t} \mathrm{ha}^{-1}$ and $32.69 \mathrm{t} \mathrm{ha}^{-1}$ for Melba and Seledyn cultivars, respectively (Table 3). On average, for the two studied melon cultivars, the highest marketable fruit yield was recorded in 2014. With the drip irrigation and broadcast nitrogen fertilization, the marketable yield was $34.95 \mathrm{t} \mathrm{ha}^{-1}$, and in the field with the drip irrigation and fertigation with nitrogen, the yield of fruits was $39.85 \mathrm{t} \mathrm{ha}^{-1}$. The lowest values of this parameter were recorded in 2015, when the marketable yield was $19.96 \mathrm{tha}^{-1}$ and $22.68 \mathrm{tha}^{-1}$, respectively, for the control and for drip irrigation combined with nitrogen fertigation. Compared to the control, the liquid fertigation significantly increased the fruit yield of Melba and Seledyn cultivars by $12.5 \%$ and $13.6 \%$, respectively. There was no significant interaction between irrigation treatment and cultivars.

Table 3. Influence of drip fertigation on the total marketable yield of fruits ( $\left.\mathrm{t} \mathrm{ha}^{-1}\right)$ of Melba and Seledyn melon cultivars in the years 2013-2015.

\begin{tabular}{|c|c|c|c|c|c|}
\hline \multirow{2}{*}{ Irrigation Treatment } & \multirow{2}{*}{ Cultivar } & \multicolumn{3}{|c|}{ Years of Study } & \multirow{2}{*}{$\begin{array}{l}\text { Mean for } \\
2013-2015\end{array}$} \\
\hline & & 2013 & 2014 & 2015 & \\
\hline \multirow{3}{*}{$\begin{array}{l}\text { Drip irrigation + broadcast nitrogen } \\
\text { fertilization (control) }\end{array}$} & Melba & 32.47 & 31.62 & 15.04 & 26.38 \\
\hline & Seledyn & 34.92 & 38.27 & 24.89 & 32.69 \\
\hline & Mean & 33.70 & 34.95 & 19.96 & 29.54 \\
\hline \multirow{3}{*}{$\begin{array}{l}\text { Drip irrigation }+ \text { nitrogen } \\
\text { fertigation }\end{array}$} & Melba & 35.37 & 35.66 & 18.01 & 29.68 \\
\hline & Seledyn & 39.95 & 44.04 & 27.36 & 37.12 \\
\hline & Mean & 37.66 & 39.85 & 22.68 & 33.40 \\
\hline \multicolumn{2}{|c|}{$\mathrm{LSD}_{0.05}$ for irrigation treatment ${ }^{1}$} & 2.182 & 4.624 & 1.828 & 1.902 \\
\hline \multicolumn{2}{|c|}{$\mathrm{LSD}_{0.05}$ for cultivar } & 1.913 & 2.380 & 2.053 & 2.198 \\
\hline \multicolumn{2}{|c|}{ Interaction } & n.s. & n.s & n.s. & n.s. \\
\hline
\end{tabular}

${ }^{1}$ LSD $=$ the lowest significant difference (Tukey's confidence half-interval) at $p<0.05 ;$ n.s. - not significant at $p<0.05$.

Some studies have previously confirmed the beneficial effect of irrigation combined with fertilization on the development of plants of the Cucurbitaceae family during cultivation on light soils. The marketable yield of watermelon grown on light soil in Central Poland under the influence of irrigation combined with nitrogen fertilization increased 
by an average of $21 \%$ [23]. In addition, in the cultivation of watermelon performed in semi-arid regions of Brazil, on the sandy soil with low retention capacity of water and low nutrient levels, the authors reported a significant effect of irrigation and nitrogen fertigation on the plant growth, increasing the yield by $64 \%$ [37]. In the study presented in this paper, the marketable yield of melon fruits was comparable to the yields obtained in research performed in other soil and climate conditions in other regions of the world. In a study carried out in Turkey, the yield of melon ranged from $18.0 \mathrm{tha}^{-1}$ to $32.4 \mathrm{t} \mathrm{ha}^{-1}$ depending on the irrigation method [38], and from $8.2 \mathrm{tha}^{-1}$ to $43.8 \mathrm{tha}^{-1}$ depending on the year of research and the type of irrigation system [39]. In an experiment carried out under field conditions with furrow irrigation in Northwest China, near to the Tengger dessert, the yield of melon ranged from $19.6 \mathrm{tha}^{-1}$ to $27.8 \mathrm{tha}^{-1}$ [40]. In research performed in Northern Jordan, melon fruit yields ranged from $15.6 \mathrm{tha}^{-1}$ to $23.5 \mathrm{t} \mathrm{ha}^{-1}$ depending on irrigation quantity [41]. In other studies carried out in Turkey, different irrigation systems and nitrogen levels affected the fruit yield of melon [42]. In the above research, by analyzing different levels of melon irrigation and fertilization, positive effects of combining nitrogen fertilization at a dose $60 \mathrm{~kg} \mathrm{~N} \mathrm{ha}^{-1}$ and drip irrigation were observed. As a result of these experiments, the fruit yield of melon was $59.77 \mathrm{t} \mathrm{ha}^{-1}$.

In the present study, a significant influence of the cultivar on the marketable yield of melon fruit was also noticed. The marketable yield of fruits of the Seledyn cultivar was higher by $24.5 \%$ compared to the Melba cultivar. Significant relationships between the yield characteristics and the cultivar of watermelon have already been observed in previous studies, the purpose of which was to compare the effects of irrigation and fertilization on the fruit yield $[23,43,44]$.

The increase in the marketable yield of melon fruits results primarily from a significant increase in the single fruit weight. The lowest total marketable yield of fruits and weight of a single fruit was obtained in 2015 (Tables 3 and 4). According to meteorological data, 2015 was very dry. The total rainfall in the period from April to September was only $193.3 \mathrm{~mm}$ (62\% of the mean for the long-term period 1986-2015). The average air temperatures during the growing season in April, May, June, and July were lower than the mean for the long-term period, $1986-2015$, by $0.6^{\circ} \mathrm{C}, 0.9^{\circ} \mathrm{C}, 0.6^{\circ} \mathrm{C}$, and $0.3{ }^{\circ} \mathrm{C}$, respectively (Table 1 ). Water deficits negatively affect the development of the melon, as it is a photophilous and thermophilic species, with a very high water requirement [8,9]. The melon plants of the Seledyn cultivar produced fruits of significantly greater weight than the plants of the Melba cultivar (Table 4). The use of drip fertigation with nitrogen significantly increased the average melon fruit weight of both the Melba cultivar by $0.12 \mathrm{~kg}$ (average fruit weight $0.76 \mathrm{~kg}$ ) and the Seledyn cultivar by $0.19 \mathrm{~kg}$ (average fruit weight $1.15 \mathrm{~kg}$ ). There was no significant interaction between irrigation treatment and cultivar. Melba is an early cultivar with an average weight of one fruit ranging from $0.5 \mathrm{~kg}$ to $0.7 \mathrm{~kg}$ [8]. In turn, the Seledyn cultivar is one of the very early ones with fruit larger than Melba, weighing up to $1.4 \mathrm{~kg}$. For comparison, in the study carried out in Turkey, depending on the irrigation method, the weight of melon fruit ranged from $0.8 \mathrm{~kg}$ to $1.2 \mathrm{~kg}$ [38].

The nutritive values of melons are presented in the Table 5 . The content of dry matter, total sugars, monosaccharides, ascorbic acid, total carotenoids, and polyphenols depended on both studied factors: drip irrigation and the cultivar. Drip irrigation combined with nitrogen fertigation significantly increased the concentration of studied components in relation to the control: for dry matter, by 1.7 points on average, total sugars by 14.1 points, monosaccharides by 17.3 points, ascorbic acid by 10.4 points, total carotenoids by 4.5 points, and total polyphenols by 10.8 points. In the study published by Ouzounidou et al. [45],

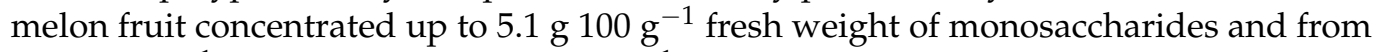

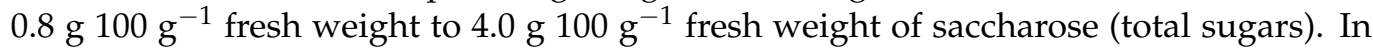
the present experiment, similar results were obtained if we converted our figures into $g$ $100 \mathrm{~g}^{-1}$ fresh weight; the levels of total carbohydrates and monosaccharides in the edible parts of melon were significantly affected by the cultivar and irrigation treatments. Seledyn contained significantly more dry matter, total sugars, and monosaccharides than Melba. In 
the studies presented by Wichrowska et al. [46], irrigation also had a positive effect on the concentration of reducing sugars and vitamin C in Cucurbitaceae, as in the present study. Melba contained significantly more ascorbic acid, total carotenoids, and polyphenols than Seledyn. Ouzounidou et al. [45] reported that the L-ascorbic acid concentration of melon fruit ranged from $13 \mathrm{mg} 100 \mathrm{~g}^{-1}$ fresh weight to $28 \mathrm{mg} 100 \mathrm{~g}^{-1}$ fresh weight. Substantially lower concentrations of this acid, in the range of $8 \mathrm{mg} 100 \mathrm{~g}^{-1}$ fresh weight to $13 \mathrm{mg} 100 \mathrm{~g}^{-1}$ fresh weight, were noted by Lin et al. [47]. The results of ascorbic acid concentration in the presented studies ranged between $14.5 \mathrm{mg} 100 \mathrm{~g}^{-1}$ fresh weight and $20.3 \mathrm{mg} 100 \mathrm{~g}^{-1}$ fresh weight and depended also on the irrigation treatment. Moreover, irrigation with fertilization increased the concentration of nutrients also in Cucurbita maxima Duch. [22].

Table 4. Influence of drip fertigation on the single fruit weight $(\mathrm{kg})$ of Melba and Seledyn melon cultivars in the years 2013-2015.

\begin{tabular}{|c|c|c|c|c|c|}
\hline \multirow{2}{*}{ Irrigation Treatment } & \multirow{2}{*}{ Cultivar } & \multicolumn{3}{|c|}{ Year of Study } & \multirow{2}{*}{$\begin{array}{l}\text { Mean for } \\
2013-2015\end{array}$} \\
\hline & & 2013 & 2014 & 2015 & \\
\hline \multirow{3}{*}{$\begin{array}{l}\text { Drip irrigation }+ \text { broadcast nitrogen } \\
\text { fertilization (control) }\end{array}$} & Melba & 0.55 & 0.87 & 0.50 & 0.64 \\
\hline & Seledyn & 0.93 & 1.26 & 0.69 & 0.96 \\
\hline & Mean & 0.74 & 1.06 & 0.59 & 0.80 \\
\hline \multirow{3}{*}{$\begin{array}{c}\text { Drip irrigation }+ \text { nitrogen } \\
\text { fertigation }\end{array}$} & Melba & 0.79 & 0.94 & 0.56 & 0.76 \\
\hline & Seledyn & 1.17 & 1.39 & 0.89 & 1.15 \\
\hline & Mean & 0.98 & 1.17 & 0.73 & 0.96 \\
\hline \multicolumn{2}{|c|}{$\mathrm{LSD}_{0.05}$ for irrigation treatment ${ }^{1}$} & 0.175 & 0.100 & 0.109 & 0.133 \\
\hline \multicolumn{2}{|c|}{$\mathrm{LSD}_{0.05}$ for cultivar } & 0.199 & 0.168 & 0.096 & 0.134 \\
\hline \multicolumn{2}{|c|}{ Interaction } & n.s. & n.s & n.s. & n.s. \\
\hline
\end{tabular}

${ }^{1} \mathrm{LSD}=$ the lowest significant difference (Tukey's confidence half-interval) at $p<0.05 ;$ n.s. - not significant at $p<0.05$.

Table 5. Influence of drip fertigation on the selected components of nutritive value of Melba and Seledyn melon cultivars (mean for the years 2013-2015).

\begin{tabular}{|c|c|c|c|c|c|c|c|}
\hline Irrigation Treatment (I) & $\begin{array}{l}\text { Cultivar } \\
\text { (I) }\end{array}$ & $\begin{array}{c}\text { Dry } \\
\text { Matter (\%) }\end{array}$ & $\begin{array}{l}\text { Total Sugar } \\
\left(\mathrm{g} \mathrm{kg}^{-1} \mathrm{FM}\right)\end{array}$ & $\begin{array}{l}\text { Monosaccharides } \\
\quad\left(\mathrm{g} \mathrm{kg}^{-1} \mathrm{FM}\right)\end{array}$ & $\begin{array}{l}\text { Ascorbic Acid } \\
\left(\mathrm{mg} \mathrm{kg}^{-1} \mathrm{FM}\right)\end{array}$ & $\begin{array}{c}\text { Total } \\
\text { Carotenoids } \\
\left(\mathrm{mg} \mathrm{kg}^{-1}\right. \\
\text { FM) }\end{array}$ & $\begin{array}{c}\text { Total } \\
\text { Polyphenols } \\
\text { (mg GAE } \\
\text { kg }^{-1} \text { FM) }\end{array}$ \\
\hline \multirow{3}{*}{$\begin{array}{c}\text { Drip irrigation + } \\
\text { broadcast nitrogen } \\
\text { fertilization (control) }\end{array}$} & Melba & 7.75 & 38.47 & 25.50 & 182.47 & 248.13 & 58.50 \\
\hline & Seledyn & 8.54 & 73.53 & 57.53 & 144.67 & 88.50 & 52.23 \\
\hline & Mean & 8.15 & 56.00 & 41.52 & 163.57 & 168.32 & 55.37 \\
\hline \multirow{3}{*}{$\begin{array}{l}\text { Drip irrigation + nitrogen } \\
\text { fertigation }\end{array}$} & Melba & 7.95 & 45.80 & 36.47 & 202.80 & 256.37 & 62.80 \\
\hline & Seledyn & 8.63 & 84.53 & 63.97 & 162.27 & 96.27 & 61.27 \\
\hline & Mean & 8.29 & 65.17 & 50.22 & 182.54 & 176.32 & 62.04 \\
\hline \multirow{2}{*}{ Mean } & Melba & 7.85 & 42.14 & 30.99 & 192.64 & 252.25 & 60.65 \\
\hline & Seledyn & 8.59 & 79.03 & 60.75 & 153.47 & 92.39 & 56.75 \\
\hline \multicolumn{2}{|l|}{ Mean } & 8.22 & 60.58 & 45.87 & 173.05 & 172.32 & 58.70 \\
\hline \multicolumn{2}{|c|}{$\mathrm{LSD}_{0.05}$ for irrigation treatment (I) ${ }^{1}$} & 0.076 & 2.050 & 0.745 & 3.867 & 3.462 & 1.926 \\
\hline \multicolumn{2}{|c|}{$\mathrm{LSD}_{0.05}$ for cultivar (II) } & 0.321 & 0.967 & 0.953 & 2.501 & 2.028 & 0.895 \\
\hline \multicolumn{2}{|c|}{$\mathrm{LSD}_{0.05}$ for interaction (I/II) } & n.s. & 2.226 & 1.187 & n.s. & n.s. & 2.086 \\
\hline
\end{tabular}

${ }^{1}$ LSD $=$ the lowest significant difference (Tukey's confidence half-interval) at $p<0.05 ;$ n.s. - not significant at $p<0.05$.

\section{Conclusions}

The results of this study indicate that on loose sandy soil with low water capacity and nutrients, melon plants should be drip-fertigated with nitrogen, in order to obtain the best effects. As compared to the control (drip irrigation combined with nitrogen fertilization), the fertigation supplying nitrogen to the plants, used during the cultivation of two melon cultivars, Melba and Seledyn, on a loose sandy soil in Central Poland, significantly increased the total marketable fruit yield by $12.5 \%$ for Melba and by $13.6 \%$ for Seledyn. Compared to the control, drip fertigation also increased the weight of single fruits by $0.12 \mathrm{~kg}$ for Melba and by $0.19 \mathrm{~kg}$ for Seledyn. Drip irrigation combined with nitrogen fertigation significantly and positively influenced nutritive value, affecting the 
increase in dry matter, total sugars, monosaccharides, ascorbic acid, total carotenoids, and polyphenols. Melba contained significantly more ascorbic acid, total carotenoids, and polyphenols than Seledyn, while Seledyn contained significantly more dry matter, total sugars, and monosaccharides.

Our studies fill a gap in the existing scientific literature and show that on a very light soil in a region with very low precipitation within Central Europe (Central Poland), the use of drip irrigation and nitrogen fertigation is effective for the cultivation of melon.

Author Contributions: Conceptualization, R.R., S.R. and A.F.; methodology, R.R., S.R. and A.F.; software, R.R., S.R. and A.F.; validation, R.R., P.-F.F. and P.S.; formal analysis, R.R., P.-F.F. and P.S.; investigation, R.R., S.R., A.F. and D.W.; resources, R.R. and S.R.; data curation, R.R., S.R., A.F. and D.W.; writing一original draft preparation, R.R., S.R., A.F., B.J., D.W., W.P., P.P., H.A.S., P.S. and D.L.; writing-review and editing, R.R., S.R., A.F., B.J., D.W., W.P., P.P. and P.S.; visualization, R.R., S.R., B.J., P.P., H.A.S., P.-F.F. and D.L.; supervision, R.R., S.R., B.J., P.P. and P.-F.F.; project administration, R.R.; funding acquisition, P.P. All authors have read and agreed to the published version of the manuscript.

Funding: This research received no external funding.

Institutional Review Board Statement: Not applicable.

Informed Consent Statement: Not applicable.

Data Availability Statement: Not applicable.

Conflicts of Interest: The authors declare no conflict of interest.

\section{References}

1. FAO (Food and Agriculture Organization of the United Nations). Faostat Database Results. 2018. Available online: http: //www.fao.org/home/en/ (accessed on 2 October 2020).

2. Pitrat, M. Melon. In Vegetables I. Handbook of Plant Breeding; Prohens, J., Nuez, F., Eds.; Springer: New York, NY, USA, 2008; Volume 1.

3. Parle, M.; Singh, K. Musk melon is Eat-Must melon. Int. Res. J. Pharm. Med. Sci. 2011, 2, 52-57.

4. Vishwakarma, V.K.; Gupta, J.K.; Upadhyay, P.K. Pharmacological importance of Cucumis melo L.: An overview. Asian J. Pharm. Clin. Res. 2017, 10, 8-12. [CrossRef]

5. Gómez-García, R.; Campos, D.A.; Oliveira, A.; Aguilar, C.N.; Madureira, A.R.; Pintado, M. A chemical valorisation of melon peels towards functional food ingredients: Bioactives profile and antioxidant properties. Food Chem. 2021, 335, 127579. [CrossRef] [PubMed]

6. Mallek-Ayadi, S.; Bahloul, N.; Kechaou, N. Characterization, phenolic compounds and functional properties of Cucumis melo L. peels. Food Chem. 2017, 221, 1691-1697. [CrossRef]

7. RCCT. Polish National List of Vegetable Plant Varieties; Research Centre for Cultivar Testing: Słupia Wielka, Poland, $2020 ;$ p. 22.

8. Gajc-Wolska, J.; Przybył, J. Warzywa Dyniowate [Pumpkin Vegetables]; Działkowiec: Warszawa, Poland, 2005.

9. Fabeiro, C.; Martin de Santa Olalla, F.; De Juan, J.A. Production of muskmelon (Cucumis melo L.) under controlled deficit irrigation in a semi-arid climate. Agric. Water Manag. 2002, 54, 93-105. [CrossRef]

10. Kaniszewski, S. Nawadnianie Warzyw Polowych [Irrigation of Field Vegetables]; Plantpress: Kraków, Poland, $2005 ;$ pp. 1-85.

11. Hartz, T.K. Effects of drip irrigation scheduling on muskmelon yield and quality. Sci. Hortic. 1997, 69, 117-122. [CrossRef]

12. Barboza, D.S.; Ferreira, J.A.; Rammana, T.V.; Rodríguez, V.P. Crop water stress index and water use efficiency for melon (Cucumid melo L.) on different irrigation regimes. Agric. J. 2007, 2, 31-37.

13. Yildirim, O.; Halloran, N.; Cavusoglu, S.; Sengul, N. Effects of different irrigation programs on the growth, yield, and fruit quality of drip-irrigated melon. Turk. J. Agric. For. 2009, 33, 243-255.

14. Leskovar, D.I.; Ward, J.C.; Sprague, R.W.; Meiri, A. Yield, quality and water use efficiency of muskmelon affected by irrigation and transplanting versus direct seeding. HortScience 2001, 36, 286-291. [CrossRef]

15. Sengul, N.; Yildirim, O.; Halloran, N.; Cavusoglu, S.; Dogan, E. Yield and fruit quality response of drip-irrigated melon to the duration of irrigation season. Toprak Su. Dergisi. 2014, 3, 90-101. [CrossRef]

16. Coolong, T. Evaluation of shallow subsurface drip irrigation for the production of acorn squash. HortTechnology 2016, 26, 436-443. [CrossRef]

17. Ayoola, O.T.; Adeniyan, O.N. Influence of poultry manure and NPK fertilizer on yield and yield components of crops under different cropping systems in south west Nigeria. Afr. J. Biotechnol. 2006, 5, 1386-1392.

18. Paula, J.A.A.; Medeiros, J.F.; Miranda, N.O.; Oliveira, F.A.; Lima, C.J.G.S. Metodologia para determinação das necessidades nutricionais de melão e melancia. Rev. Bras. Eng. Agríc. Ambient. 2011, 15, 911-916. [CrossRef] 
19. Wichrowska, D.; Rolbiecki, R.; Rolbiecki, S.; Figas, A.; Jagosz, B.; Ptach, W. Influence of drip irrigation on nutritive value of winter squash 'Rouge vif d'Etampes' after harvest and storage. Infrastruct. Ecol. Rural Areas 2017, III/2, 1167-1175.

20. Wichrowska, D.; Rolbiecki, R.; Rolbiecki, S.; Jagosz, B.; Ptach, W.; Kazula, M.; Figas, A. Concentrations of some chemical components in white asparagus spears depending on the cultivar and post-harvest irrigation treatments. Folia Hortic. 2018, 30 , 147-154. [CrossRef]

21. Battilani, A.; Solimando, D. Yield, quality and nitrogen use efficiency of fertigated watermelon. Acta Hortic. 2006, 700, 85-90. [CrossRef]

22. Rolbiecki, R.; Rolbiecki, S.; Figas, A.; Wichrowska, D.; Jagosz, B.; Ptach, W. The efficiency of drip fertigation in cultivation of winter squash 'Gomez' on the very light soil. Infrastruct. Ecol. Rural Areas 2017, III/2, 1201-1211.

23. Rolbiecki, R.; Rolbiecki, S.; Piszczek, P.; Figas, A.; Jagosz, B.; Ptach, W.; Prus, P.; Kazula, M.J. Impact of nitrogen fertigation on watermelon yield grown on the very light soil in Poland. Agronomy 2020, 10, 213. [CrossRef]

24. Żakowicz, S.; Hewelke, P. Analiza susz atmosferycznych i glebowych jako kryterium potrzeby nawodnień w danym regionie kraju [Analysis of atmospheric and soil droughts as a criterion for the need for irrigation in a given region of the country]. Zesz. Probl. Postęp. Nauk Rol. 1990, 387, 193-198.

25. Rzekanowski, C. Perspektywy rozwoju nawodnień w Polsce [Prospects for the development of irrigation in Poland]. Wiadomości Melioracyjne i Łakarskie 2010, 2, 55-58.

26. Łabędzki, L.; Kanecka-Geszke, E.; Bąk, B.; Słowińska, S. Estimation of reference evapotranspiration using the FAO PenmanMonteith method for climatic conditions of Poland. In Evapotranspiration; Łabedzki, L., Ed.; InTech: Rijeka, Croatia, 2011; pp. 1-446.

27. Żarski, J. Tendencje zmian klimatycznych wskaźników potrzeb nawadniania roślin w rejonie Bydgoszczy [Trends in changes of climatic indices for irrigation needs of plants in the region of Bydgoszcz]. Infrastruct. Ecol. Rural Areas 2011, 5, $29-37$.

28. Rolbiecki, R.; Rolbiecki, S. Wpływ nawadniania kroplowego na plonowanie dyni olbrzymiej odmiany 'Rouge vif d'Etampes' uprawianej na glebie bardzo lekkiej [Influence of drip irrigation on yields of winter squash cv. 'Rouge vif d'Etampes'cultivated on the very light soil]. Infrastruct. Ecol. Rural Areas 2012, 2, 191-197.

29. Rolbiecki, R.; Rolbiecki, S.; Podsiadło, C.; Wichrowska, D.; Figas, A.; Jagosz, B.; Ptach, W. Influence of drip irrigation on the yielding of summer squash 'White Bush' under rainfall-thermal conditions of Bydgoszcz and Stargard. Infrastruct. Ecol. Rural Areas 2017, III/2, 1229-1240.

30. PSSS (Polish Society of Soil Science). Klasyfikacja uziarnienia gleb i utworów mineralnych [Classification of the grain size of soils and mineral deposits]. Roczniki Gleboznawcze 2009, 60, 5-16.

31. AOAC (Association of Official Analytical Chemists). Official Methods of Analysis; AOAC International: Arlington, VA, USA, 2002.

32. Talburt, W.F.; Smith, O. Potato Processing; Van Nostrand Reinhold Co.: New York, NY, USA, 1987; pp. 371-474.

33. Kapur, A.; Hasković, A.; Čopra-Janićijević, A.; Klepo, L.; Topčagić, A.; Tahirović, I.; Sofić, E. Spectrophotometric analysis of total ascorbic acid content in various fruits and vegetables. Bull. Chem. Technol. Bosnia Herzeg. 2012, 38, $39-42$.

34. Herrero-Martínez, J.M.; Eeltink, S.; Schoenmakers, P.J.; Kok, W.T.; Ramis-Ramos, G. Determination of major carotenoids in vegetables by capillary electrochromatography. J. Sep. Sci. 2006, 29, 660-665. [CrossRef]

35. Polish Standard. Fruit and Vegetable Juices-Journal of Separation Science Determination of Total Carotenoid Content and Individual Carotenoid Fractions (PN-EN 12136); Polish Committee for Standardization: Warszawa, Poland, 2000.

36. Singleton, V.L.; Orthofer, R. Analysis of total phenols and other oxidation substrates and antioxidants by means of Folin-Ciocalteu reagent. In Methods in Enzymology; Abelson, J.N., Simon, M.I., Sies, H., Eds.; Academic Press: Burlington, MA, USA, 1999; pp. 152-178.

37. Fernandes, C.N.V.; Azevedo, B.M.D.; Neto, J.R.N.; Viana, T.V.D.A.; Sousa, G.G.D. Irrigation and fertigation frequencies with nitrogen in the watermelon culture. Bragantia 2014, 73, 106-112. [CrossRef]

38. Sensoy, S.; Ertek, A.; Gedik, I. Irrigation frequency and amount affect yield and quality of field-grown melon (Cucumis melo L.). Agric. Water Manag. 2007, 88, 269-274. [CrossRef]

39. Dogan, E.; Kirnak, H.; Berakatoglu, K.; Bilgel, L.; Surucu, A. Water stress imposed on muskmelon with subsurface and surface drip irrigation systems under semi-arid climatic conditions. Irrig. Sci. 2008, 20, 131-138. [CrossRef]

40. Huang, C.-H.; Xue, X.; You, Q.-G.; Zong, L.; Luo, J. Effects of irrigation frequency on yield and quality of melon under fieldconditions in Minqin oasis. Int. Res. J. Public Environ. Health 2016, 3, 293-299.

41. Al-Mefleh, N.K.; Samarah, N.; Zaitoun, S.; Al-Ghzawi, A.A.M. Effect of irrigation levels on fruit characteristics, total fruit yield and water use efficiency of melon under drip irrigation system. J. Food Agric. Environ. 2012, 10, 540-545.

42. Simsek, M.; Comlekcioglu, N. Effects of different irrigation regimes and nitrogen levels on yield and quality of melon (Cucumis melo L.). Afr. J. Biotechnol. 2011, 10, 10009-10018.

43. Wakindiki, I.I.C.; Kirambia, R.K. Supplemental irrigation effects on yield of two watermelon (Citrulus lanatus) cultivars under semiarid climate in Kenya. Afr. J. Agric. Res. 2011, 6, 4862-4870.

44. da Costa, A.R.; de Medeiros, J.F.; Porto Filho, F.D.Q.; da Silva, J.S.; Costa, F.G.; de Freitas, D.C. Production and quality of watermelon cultivated with water of different salinities and doses of nitrogen. Rev. Bras. Eng. Agríc. Ambient. 2013, 17, 947-954.

45. Ouzounidou, G.; Papadopoulou, P.; Giannakoula, A.; Ilias, I. Effect of plant growth regulators on growth, physiology and quality characteristics of Cucumis melo L. Veg. Crops Res. Bull. 2006, 65, 127-135. 
46. Wichrowska, D.; Wojdyła, T.; Rolbiecki, S.; Rolbiecki, R.; Piszczek, P. The content of chosen components in fruit of polish watermelon cultivar 'Bingo' as dependent on way of the seedling production and irrigation. Pol. J. Food Nutr. Sci. 2007, 57, 147-149.

47. Lin, D.; Huang, D.; Wang, S. Effect of potassium levels on fruit quality of muskmelon in soilless medium culture. Sci. Hortic. 2004, 102, 53-60. [CrossRef] 